\title{
The Role of Calcium-Dependent Gene Expression in Autism Spectrum Disorders: Lessons from MeCP2, Ube3a and Beyond
}

\author{
Zilong Qiu Ju Cheng \\ Institute of Neuroscience, Shanghai Institute of Biological Sciences, Chinese Academy of Sciences, \\ Shanghai, PR China
}

\section{Key Words}

Calcium $\cdot$ Transcription $\cdot \mathrm{MeCP} 2 \cdot$ Copy number variations

\begin{abstract}
During the last decade, autism spectrum disorders (ASD) have become the center of attention where several branches of modern biology unexpectedly meet, such as neural development, molecular biology, epigenetics, neurophysiology and psychiatry. This review will focus on the molecular mechanism by which calcium-dependent gene expression regulates brain development and how ASD may occur if this process is compromised. Specifically, the studies of the calcium-dependent transcriptional repressor MeCP2 gave us much insight about how abnormal development may lead to ASD. Most recently, studies about Ube3a, a critical component of the ubiquitination system enzyme, shed light on how neural activity regulates synapse function through the protein degradation pathway. Taken together, these studies suggest that ASD may be caused by the incapability of neurons to generate adaptive responses via regulating gene expression upon incoming activity.
\end{abstract}

Copyright $\odot 2010$ S. Karger AG, Base

\section{Introduction}

Autism spectrum disorders (ASD) are characterized by late onset of social interaction defects and can be diagnosed in patients as young as toddlers [1]. Prevalence of autistic spectrum disorders over last 2 decades has caught the attention of government, academia and the rest of society [2]. Although genetic clues from ASD cases are continually being identified, a clear picture of genetic causes of ASD is still missing. Abnormalities throughout the genome have been found for several decades, such as chromosome X, 2, 3, 5, 7, 11, 13, 15, 16 and 22 [3-13]. ASD is certainly genetically associated; however, how many genes are involved has not yet been determined.

The late onset of autistic symptoms strongly suggests that some critical steps in postnatal brain development may be disrupted in patients. Based on the pioneering work of Hubel and Wiesel [14-16] in the 1960s, it is widely appreciated that postnatal brain development is more sensitive to experience input than predetermined by genetic information. Evidence accumulated over the years has led us to realize that genetic information lays down the gross connection map for the brain, whereas precise refinement of neuronal connections will take place in every individual brain in response to sensory input or, more precisely, combined effects from extrinsic and intrinsic activity of the brain.

\section{KARGER \\ Fax +4161306 1234 E-Mail karger@karger.ch} www.karger.com
Zilong Qiu

Institute of Neuroscience, Shanghai Institute of Biological Sciences

Chinese Academy of Sciences

Yueyang Road 320, Shanghai 200031 (PR China)

Tel. +86 215492 1806, Fax +86 215492 1735, E-Mail zqiu@ion.ac.cn 
The way neural activity modifies the neuronal connections is due to electric pulses that neurons receive. These induce chemical reactions within the cell, which could turn genetic switches on the chromosome on or off, and turn on new protein synthesis, or shut down existing ones. These adaptive responses neurons generate strengthened or weakened synapses, which are specified connections between neurons. Thus, neural functions of the brain are optimized by sensory inputs and, finally, allow the organism to develop and survive in different environments [17].

The molecular mechanism by which neural activity turns on gene expression has been revealed by a series of molecular biology studies starting in the 1980s [18, 19]. The 2nd messenger calcium ion is the critical trigger to activate the intracellular signaling pathway and regulate gene expression. Indeed, several calcium-dependent transcription factors have been found to be crucial for proper postnatal neural development [20-25]. Notably, $\mathrm{MeCP} 2$, the primary mutated gene in a severe form of ASD-Rett syndrome, is a calcium-dependent transcription repressor [26-29]. Thus, MeCP2-regulated gene expression may play an important role in controlling the refinement of the neural network as well. Evidences identified over the last decades suggest that proper synaptic functions are crucial for brain development since mutations in ASD patients are found in genes which encode proteins located in synapses such as Shank 3 and neuroligins. These observations indicate that the signaling pathway from synapses to the nucleus is critical for maintaining proper physiological functions of the brain.

\section{The Genetic Cause for ASD Part I: MeCP2 and Rett Syndrome}

MeCP2, a methyl-DNA-binding protein, was cloned and characterized as a transcriptional repressor in the 1990s [27, 28]. A surprising result from human genetic studies linked this transcription regulator with Rett syndrome and ASD [29]. The human mecp2 gene is located on the $\mathrm{X}$ chromosome. Nonsense or missense mutations happening on the mecp2 gene leads to Rett syndrome in young girls since male infants with mutated mecp 2 do not survive to birth. Rett girls appear largely normal at 6 months to 1 year of age, but then develop regressive symptoms such as loss of motor functions, language skills, purposed hand movement, etc. Repetitive and autistic behaviors are often reported [30].

Activity-Dependent Gene Expression and Autism

\section{The Molecular Biology of MeCP2-Regulated Gene Expression}

MeCP2 binds preferentially to methylated DNA and recruits repressor complexes including HDAC1 and mSin3A [28]. Methylated DNA is considered as transcriptionally silent. If this repressor is dysfunctional as it is in Rett syndrome patients and mecp2 gene knockout mice, it is logical to deduce that gene expression profile will be affected by favoring upregulation of the repressed gene by $\mathrm{MeCP} 2$. However, the overall gene expression pattern remains largely unaltered in the mecp2 knockout mouse brain in comparison to the wild-type mouse brain [31]. This result suggests that the $\mathrm{MeCP} 2$ protein may carry out different functions in different cell types. If one analyzes the gene expression profile with mixed tissue of the whole brain, one may miss the difference between different cell types.

Researchers then did a more thorough study where they analyzed gene expression pattern in the hypothalamus between wild-type and 2 different kinds of genetically modified mice [32]. They found that downregulated genes were more than upregulated genes in mecp2-null mice, which implies that MeCP2 enhances gene expression. Consistent with this idea, upregulated genes are more than downregulated genes in mecp2-overexpression mice [32]. These results led the authors to conclude that $\mathrm{MeCP} 2$ does not only repress gene expression, but also activates gene expression by interacting with the calcium-dependent transcription factor CREB [32].

More direct biochemical evidence is required to explain how a methyl-DNA-binding protein activates gene expression. At the same time, one could make a few alternative explanations from the evidence presented. For example, it is possible that $\mathrm{MeCP} 2$ still functions as a repressor and strongly represses expression of some repressors. In this case, gene expression will appear to be downregulated if $\mathrm{MeCP} 2$ is absent, which is due to $\mathrm{MeCP} 2$-regulated repressors being de-repressed. Consistently, if the mecp2 gene is overexpressed, these unknown repressors will be inhibited, resulting in increased gene expression. In the end, it appears that $\mathrm{MeCP} 2$ acts as an transcriptional activator. Therefore, without any support from direct biochemical evidence, this model is still debatable.

In 2003, 2 groups independently reported that MeCP2 is quickly phosphorylated by calmodulin-dependent kinases and regulates gene expression in response to neural activity. This important finding led us to a key fact that the transcriptional regulatory activity of $\mathrm{MeCP} 2$ is sensi-

Neurosignals 2010;18:72-81 
tive to calcium signaling $[33,34]$. Researchers also reported that $\mathrm{MeCP} 2$ regulated the expression of a critical neurotrophin-brain-derived neurotrophin factor (BDNF). Methylation modification on DNA is thought to be stable and static. However, the promoter of the BDNF gene changes its methylation state within a couple of hours upon depolarization of the neuron. MeCP2 binds to the BDNF gene promoter in the basal state. When calcium signaling is activated, the serine 421 site $\mathrm{MeCP} 2$ is phosphorylated within a few minutes, which leads MeCP2 to be released from the promoter [33, 34]. These findings indicate that $\mathrm{MeCP} 2$ is able to regulate gene expression in response to neural activity.

However, the story about MeCP2 and BDNF is not settled yet. Contradictory results have been reported from different labs. According to the original model, BDNF is found to upregulate in mecp2-null neurons [33]. A study from another lab showed different results in this case: they found overexpression of MeCP2 enhances BDNF expression, whereas the MeCP2 level is lower in Rett syndrome patients than normal samples [35]. There are a few more reports where researchers have found that $\mathrm{MeCP} 2$ protein and mRNA levels indeed go down in Rett syndrome patients and mecp2 knockout mice [36]. These debates suggest that the regulatory mechanism by which $\mathrm{MeCP} 2$ controls BDNF expression remains to be understood. Regulation could happen not only at the transcription level, but also at the translation level. Is there a 2 nd switch regulating $\mathrm{MeCP} 2$-dependent BDNF expression which is also sensitive to neural activity?

\section{The Role of MeCP2 in Neural Development and Plasticity}

The importance of MeCP2 for neural development is undoubtable. A few genetically modified mice have been made in order to mimic Rett syndrome in mice [37-39]. These mouse lines recapitulate the main symptoms found in Rett syndrome patients, such as uncontrolled limb movement, seizures, anxiety and defects in social interaction, well.

The next question to ask is whether these mouse models exhibit any biological or physiological cell defects. Researchers soon found abnormalities in the cortical and hippocampal neurons of mecp2-null mouse [40]. Defects in dendritic structure and the excitatory synapse representation-dendritic spines have been found. It is of great importance to compare these defects with human pa- tients. However, due to difficulties of accessing human samples, it is not clear whether these defects are also present in patients.

Physiological studies with mecp2-null mice over last few years have yielded plenty of information about the defects of synaptic transmission between mecp2-deficient neurons. Researchers have found the excitatory and inhibitory balances to be disrupted in the mecp2-null brain [41]. Researchers then used neuronal culture systems to show that excitatory synaptic transmission is specifically compromised $[42,43]$. Excitatory synapse development also shows structural defects, such as decreased colocalization of the postsynaptic marker PSD95 and presynaptic protein synapsin [42].

In the mouse model for Rett syndrome, researchers found abnormal long-term synaptic plasticity in the hippocampus of mecp2-null mice [44, 45]. These results fit well with the observations that mecp2-null mice have a compromised ability for learning and memory. However, how these molecular and cellular abnormalities lead to disrupted social behaviors in mecp2-null mice or human Rett patients are still unknown. Since Rett syndrome patients develop symptoms during the important postnatal period, there may be some critical events disrupted in patients' brains which require MeCP2. More in-depth investigations about functions of mecp2 in neural development are still needed.

\section{The Genetic Cause for ASD Part II: Ube3a and Angelman Syndrome}

The human chromosome 15q11-13 region has attracted a lot of attention over the last few years. Mutations of the maternal-inherited Ube3a gene in this region lead to Angelman syndrome, a neural developmental disorder $[46,47]$. The Ube3a gene and surrounding genes are imprinted, which means only 1 copy from the parents can express. More intriguingly, microduplications of 15q1113 are found in autism patients [48-51]. This interesting phenomenon will be discussed in the next session.

Ube3a is an E3 ligase which plays a critical role in controlling protein degradation. Over the years, it has been widely accepted that protein degradation is a crucial way by which cells maintain their own physiological stability [52]. Abnormal protein degradations have been found in many neurodegenerative disorders, such as Huntington's disease and spinocerebellar ataxia, where mutated genes code proteins containing abnormally long glycine residue repeats, leading to the formation of toxic protein aggre- 


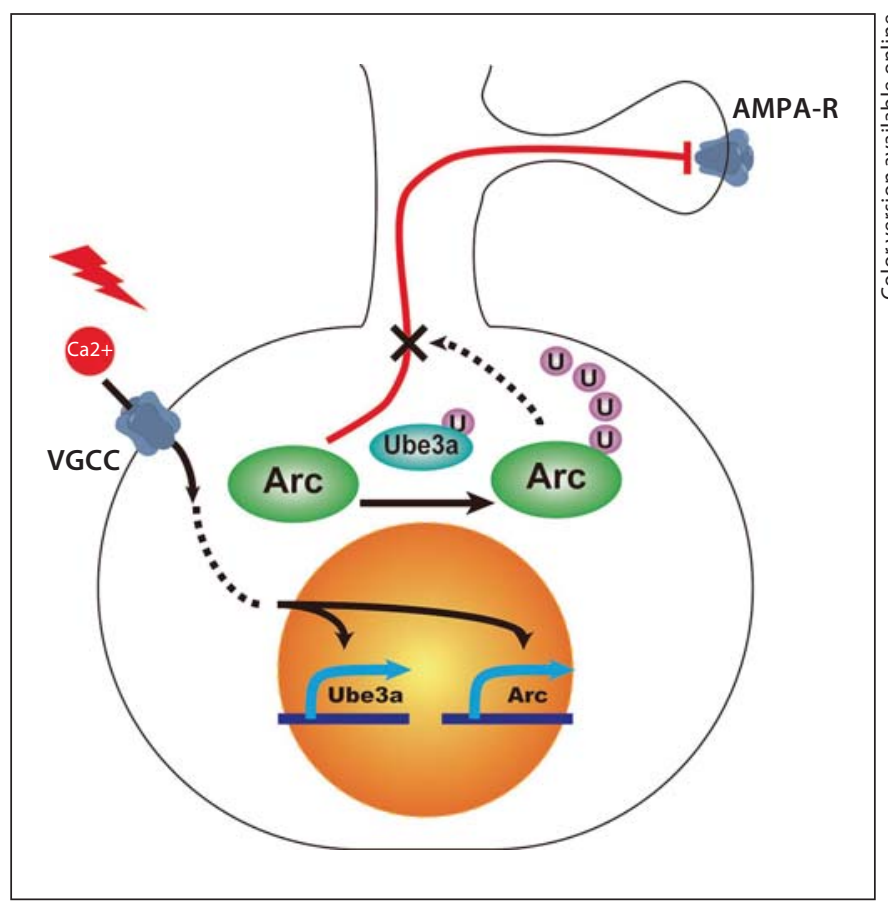

Fig. 1. The model for Ube3a regulating AMPA-R-mediated synaptic transmission. Calcium influx through voltage-gated calcium channel induces the expression of Ube3a and Arc. However, Ube3a rapidly degrades Arc, which plays a critical role in regulating AMPA receptor endocytosis. Thus, the loss of Ube3a will lead to abnormal elevation of AMPA receptor-mediated synaptic transmission.

gates which are resistant to protein degradation pathways [53-57].

In the mouse model for Angelman syndrome, researchers showed that normal postnatal development and plasticity are compromised in Ube 3 a knockout mice $[58,59]$. However, since protein degradation is a ubiquitous physiological process, why does Ube3a play such a specific role in brain development? It is speculated that Ube3a functions in a specific group of substrates which are critical for neural developmental and plasticity.

Interestingly, Ube3a has another name, E6-AP (human papilloma viruses E6-associated protein). E6-AP could ubiquitinate and degrade the critical tumor suppressor p53 [60,61]. The obvious important role of Ube3a has been underexplored in the nervous system for years. A recent study has recently helped, though, by identifying an important substrate of Ube3a [62].

Researchers showed that the expression of Ube3a is controlled by calcium signaling [62]. Furthermore, one of the Ube3a substrates is Arc, an important activity-regu- lated gene and regulator of synaptic transmission [6265]. Arc plays a negative role in regulating AMPA-R-mediated synaptic transmission [63-65]. Accordingly, authors found that AMPA receptor synaptic localization and currents decreased in Ube3a knockout mice, which is due to more Arc proteins accumulating in the neuron without Ube3a. These results are consistent with previous findings which showed the decreased excitatory synaptic transmission and formation in a mouse model for Angelman syndrome (fig. 1) [59].

Since protein ubiquitination is a universal reaction happening in almost every physiological process within the cell, it is still hard to understand why loss of Ube3a causes abnormalities in neural development. There may be some specific signatures in functionally important proteins which is processed by Ube3a during neural development. Therefore, a more comprehensive understanding of the Ube3a substrates is needed to appreciate the critical function of Ube3a in the nervous system.

\section{The Genetic Cause for ASD Part III: Shank3 and Neuroligins}

Besides transcriptional and protein degradation regulator, there are some important clues pointing to the susceptible genes of ASD directly at the synapse, such as Shank 3 and neuroligins 3 and 4 [66-69].

Shank family proteins are purified from the synapse of the neuron [70,71]. They show an important structural and functional role in regulating proper signal transduction in the synapse. Interestingly, Shank family proteins are able to induce excitatory synapse components, such as spine formation [72]. Mutations are found at the shank3 gene in human ASD patients [66]. Researchers have also found that not only loss of shank 3 may cause ASD, but also gain of shank 3 by genomic duplication may lead to ASD [67]. These findings raise important questions, which suggest that not just a certain type of synaptic transmission is critical, but that the more important issue could be the balance between excitatory and inhibitory inputs. This may explain why the shank 3 gene will more or less cause similar symptoms in the ASD patients.

Neuroligins are a class of cell adhesion molecules that play decisive roles in controlling synapse formation between neurons [73, 74]. Interestingly, the family members of neuroligins play distinct roles in regulating formation of different types of synapses [75-77]. The human genetic study identified neuroligins 3 and 4 as being highly associated with ASD cases $[69,78]$. It has been speculated 
for a while that synaptic defects may underlie cognitive dysfunctions such as autism. Researchers revealed an important mechanism with which neuroligin 3 is critical for neurons to maintain electrophysiological stability [79]. They showed that one needs to replace the wild-type neuroligin 3 with the mutant form found in the ASD patients, rather than knocking it out, to reproduce the social interaction defects in autistic patients in genetically modified mice [79]. Again, they found that the excitatory and inhibitory balance was disrupted by the mutation on neuroligin 3 [79]. This study convincingly showed that synaptic functions are directly related to certain cognitive functions.

These few lines of evidence connect the sophisticated social behaviors to the subtle defects on the synapse. We have reason to speculate that proper synaptic transmission is required for the normal brain functions. The excitatory or inhibitory input neurons receive is directly reflected by how neurons process and transmit signals to their connection partners at their postsynaptic sites. Also, the overall activity neurons receive determines whether neurons decide to undertake gene expression alternations. The calcium-dependent transcriptional regulators discussed above are downstream of synaptic transmissions, whereas proteins at the synapses directly control the incoming activity of the neuron. Thus, all of this evidence points out that the signaling pathway from synapse to the nucleus is critical for proper functions of the brain, and dysfunction of any link of it may lead to ASD.

\section{Copy Number Variations: Another Cause for ASD?}

\section{mecp2}

Rett syndrome happens in girls since baby boys who carry the mutated mecp2 gene will be too sick to survive. This rule was broken by findings that some boys who carry double copies of the mecp2 gene develop a similar form of Rett syndrome [80]. After careful investigations, researchers found that duplications in some genomic regions were quite common in genetic disorders, which is called copy number variations.

The genome is not as stable as the Parthenon. Some sensitive regions tend to break and recombine within the genome. This phenomenon was missed by the classical shotgun genome sequencing method. Now a lot of tools have been developed to explore the distribution and mechanisms of copy number variations, such as DNA microarray designed for detecting copy number varia- tions [81]. The direct consequence for a gene getting more or less copy is that the amount of gene product-protein will vary. Thus, it is not surprising that copy number variations are found in neurological disorders. If some important proteins get more or less, the normal function of the nervous system will surely be affected.

In a recent study, the patients with a double copy of mecp2 were examined for neurological symptoms [80]. Surprisingly, most of these patients appeared to have autistic phenotypes. In female patients, half of the subjects had normal or higher IQ than normal kids. Normal IQ is never seen in Rett syndrome patients, although many typical autistic kids appear to have normal or higher IQ than their peers [80]. This finding suggests that mecp2 duplication syndrome patients have unique features compared to typical Rett syndrome patients, whose symptoms are closer to classic autism.

In order to understand the consequence of the brain containing more MeCP2 protein, researchers made a transgenic mouse carrying the human mecp2 gene in a bacterial artificial chromosome [82]. Consistent with higher IQ in human patients, enhanced synaptic plasticity and learning and memory are found in this mouse. However, this mouse will still develop Rett-like symptoms in adulthood, including uncontrolled limb movement and seizures.

Taken together, these findings strongly indicate that the amount of mecp2 protein in the nervous system is critical. An interesting report in 2007 linked the expression of the mecp2 gene to neural activity [35]. Researchers found that calcium influx through L-type voltage-gated calcium channels activates expression of miRNA 132 via the classic CREB pathway. miRNA 132 in turn targets mecp2 mRNA and represses its expression. Thus, when neurons undergo strong depolarization, calcium (through L-type calcium channels) will specifically downregulate mecp2 expression [35]. Why would neurons want to decrease mecp2 expression upon stimulation? The authors proposed a model where a certain amount of $\mathrm{MeCP} 2$ protein needs to be maintained. Thus, the $\mathrm{MeCP} 2$ protein level will be tuned homeostatically according to input activity (fig. 2).

Although this model reveals a new regulatory mechanism, we have to understand comprehensively how the overexpression of mecp2 affects gene expression profile in the neuron. In the previously mentioned study, the researchers established a long list of genes whose expression is higher in the mecp2-overexpressed hypothalamus than in wild types [32]. In the future, we need to understand how mecp2 affects gene expression in an activity-depen- 
Fig. 2. Homeostatic regulation of MeCP2dependent gene expression. Calcium influx activates the CaMK pathway and triggers quick phosphorylation of MeCP2 on serine 421 (S421), which leads to the release of $\mathrm{MeCP} 2$ from its target gene, BDNF. On the other side, calcium influx will also induce the expression of miRNA 132 (miR132), which targets the MeCP2 mRNA and represses its translation. Thus, calcium signaling not only modifies MeCP2 function post-translationally but also regulates the protein level of $\mathrm{MeCP} 2$ via activity-dependent miRNA.

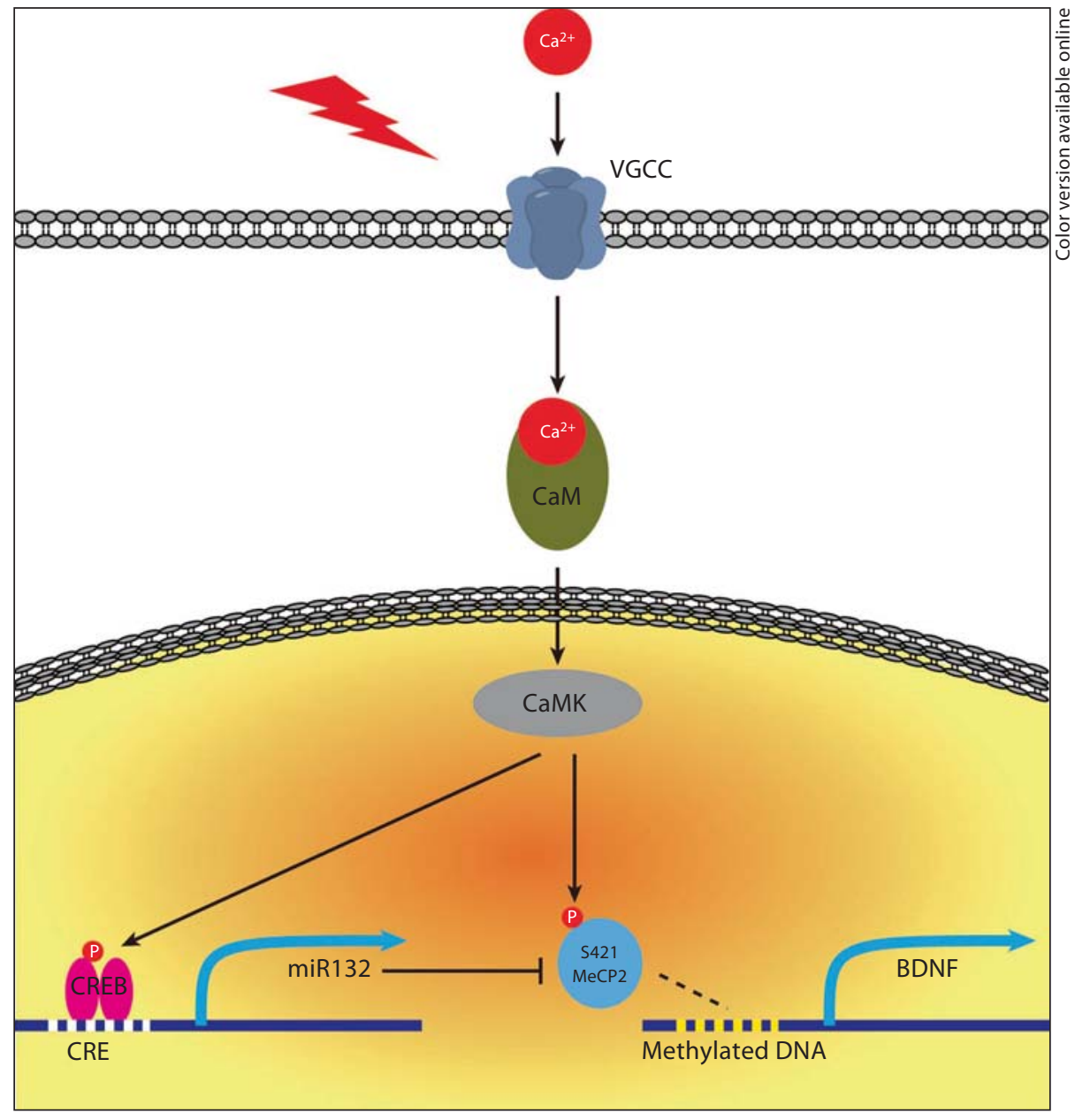

dent manner. For example, how many genes' expression will be altered upon neural activity when more MeCP2 protein is present?

\section{Ube $3 a$}

15q11-13 duplications were identified in ASD patients decades ago [51, 83]. Last year, a striking study showed that mice carrying human 15q11-13 genome segments develop autistic phenotypes and inflexibility in learning memory tasks [84]. Although the Ube3a gene is the primary target in this region, would there be any other important genes which may contribute to autistic phenotypes? If Ube3a itself were enough, it is expected that overexpressing Ube3a alone in the nervous system would phenocopy the main features of these genetically engineered mice.

When the 15q11-13 region is duplicated in the genome, it is logical to deduce that the amount of Ube3a will increase. However, this region in humans is imprinted, which increases the difficulty in explaining the consequences of genomic duplication. Indeed, the authors found only mice with paternal duplication showed defects [84]. The authors finally found enhanced expression of a snoRNA MBII52 in this region. Interestingly, paternal mutation of MBII52 and the neighbor locus of chromosome 15 lead to another mental retardation - the Prader-Willi syndrome. MBII52 snoRNA plays a critical role in regulating alternative splicing of serotonin receptor 5-HT 2C $[85,86]$. Mice carrying paternal duplication of human 15q11-13 showed increased expression of MBII52 and then an enhanced serotonin response [84]. This observation is essentially the opposite of what happened in the Prader-Willi patients, who lack MBII52 and have abnormal serotonergic transmission. Serotonin is known as an important regulator of various physiological processes. However, is this enhanced serotonin pathway 
responsible for defects in social behavior and learning memory tasks found in 15q11-13-duplicated mice or 15q11-13 duplication syndrome patients? More rigorous research needs to be done in order to provide a convincing answer.

\section{How Far Are We from a Cure?}

\section{Genetic Rescue of mecp2}

There are no obvious neurodegenerative symptoms in Rett syndrome patients and other ASD patients, which excludes the possibility of neuronal loss [30]. Since the neuronal network seems intact, would it be possible to cure the disorder by putting the wild-type gene back in?

The first attempt tried to reintroduce the wild-type mecp2 gene into the neuronal specific tau locus [87]. The authors surprisingly found that some phenotypes are indeed rescued to some extent, e.g. movement, life span, etc. However, overexpression of mecp2 exhibits strong toxicity in the mice during adulthood [87], reminding us that a mecp2 protein overdose will cause damage.

How can mecp 2 be reintroduced into the mutant brain as naturally as possible? A second round of attempts gave rise to brilliant results. In 2007, 2 labs reported that reintroduction of mecp2 significantly reversed the severe phenotypes of mecp2-null mice [88, 89]. Researchers from Edinburgh designed an elegant strategy which blocked endogenous mecp 2 expression by putting a lox $\mathrm{P}$ stop-loxP cassette in front of the genomic mecp2 locus. In this way, one could re-express mecp 2 with the endogenous regulatory mechanism by activating Cre recombinase. The first attempt was to try to strongly rescue mecp2 expression by the sharp expression Cre recombinase. Unfortunately, this treatment led to massive deaths among the mice. Maybe too much during a short time is still disastrous. Researchers next gradually activated Cre by controlling the amount of Cre to a much more moderate level. The miracle finally happened. Almost all the severe phenotypes of mecp2 knockout mice were successfully reversed! Mice were able to smoothly run around instead of slowly moving as a result of lagging back limbs [88]. Researchers carefully examined the synaptic plasticity of these rescued mice with wild-type mecp 2 and found enhanced plasticity in the mutant mice brain [88].

This groundbreaking study showed for the first time successful genetic rescue in a mouse model for ASD [88]. It has been thought that once genetic damage for brain is caused, it could never be reversed by simply adding the wild-type gene back into the adult brain. The reason could be the development of brain is a timing issue. The juvenile brain is more plastic to sensory input or environment stimulations, whereas the adult brain is more settled. Once certain developmental stages are passed, one can never rebuild the correct neural network. It seems that dogmas are always meant to be broken once again.

People are trying to find logical explanations for this striking result. We speculate that in the mecp2-null brain, neural connections are able to reconnect or rebuild given the presence of critical regulators. First, we need to fully understand which defect of mutant mecp2 is the leading cause. According to a previous report, we know the excitatory synaptic transmissions are disrupted [42]. Thus reintroduction of mecp2 will surely rescue excitatory synaptic functions. However, which target genes of mecp2 will be responsible for this effect are still unclear. More efforts are needed in order to understand the effect of mecp2-regulated gene expression.

Alternatively, if we could reliably deliver wild-type mecp2 into the brain of Rett patients, we may be able to cure Rett syndrome. Researchers have already initiated efforts to try to find a safe and efficient way to deliver mecp2 into the human brain with recombinant viralbased technology [90]. An important note of this line of research is that we must reintroduce mecp2 with its endogenous regulatory elements, since we know an overdose of mecp2 is fatal $[87,88]$. The report that mecp2 is negatively regulated by neural activity also suggests that neurons are trying to maintain the level of mecp2 at a suitable level [35].

Other than wild-type gene delivery, researchers have made some interesting observations in which enhancing synaptic transmission or intracellular cell signaling seem to have positive effects in alleviating the symptoms in mouse models for the Rett and Angelman syndromes [91, 92]. These exciting results further provide a target protein and pathway which could be used as therapeutic targets.

\section{Therapeutic RNA Strategy}

Since gene delivery is always difficult, do we have alternative strategies to manipulate mecp2 protein level in the patient's brain? Therapeutic RNA technology largely reshaped the bio-pharmaceutical landscape. Since siRNA or miRNA are small molecules, it is relatively easy to deliver, or even design, an agonist or antagonist for them. Recently, a groundbreaking report showed that systematically applying siRNA blocker efficiently inhibits func- 
tions of target siRNA and, therefore, successfully controls hepatitis $\mathrm{C}$ in a nonhuman primate model [93].

There are a few different strategies for designing therapeutic RNAs for manipulating the mecp2 protein level or mecp2 target gene expression level. Given the fact that $\mathrm{MeCP} 2$ is a transcriptional repressor, $\mathrm{MeCP} 2$ may repress expression of some miRNAs. miRNAs play critical roles in regulating gene expression by controlling the translation of mRNA [35]. Among these target miRNAs, thorough functional investigations are required to find out whether they could be used to design therapeutic RNA accordingly.

The therapeutic development for a certain group of genetic disorders will take years and collaboration between different industries to achieve efficient drugs. Given the complexity for ASD, more thorough mechanistic studies are needed in order to find target genes for therapeutic designs.

\section{Concluding Remarks}

Progress during the last decade in the study of ASD has been enormous. However, there is still plenty of work ahead of us before we understand the mechanism for ASD and can design suitable therapies for patients who usually have various symptoms. The study of calciumdependent gene expression gave us a unique opportunity with which we may understand the molecular basis for
ASD and go further to pursue therapeutic efforts. Before the study of $\mathrm{MeCP} 2$, the role for calcium-dependent gene expression was thought to solely contribute to higher cognitive functions. This line of research points out that calcium-dependent gene expression is indeed critical for tuning precise connections in the brain, and some complicated disorders may occur, e.g. ASD, if this process is disrupted.

Recent evidence from an elegant human genetic study in which researchers used genetic methods to locate several unknown genes, which may be implicated in ASD, links activity-dependent gene expression to autism even further [94]. Interestingly, they showed that expression of some of these ASD candidate genes, e.g. protocadherins, etc., are controlled by calcium signaling [94]. This finding further suggests that genes controlled by calcium signaling may be the key to understanding the molecular basis of ASD. Only if we comprehensively investigate this important physiological process may we finally get a clear picture about how the brain develops and functions.

\section{Acknowledgements}

We thank Drs. Xiang Yu, Hailan Hu, Chengyu Li and Sen Song for critical comments and valuable discussions. This work was supported by grants from The Hundreds of Talents Program and Knowledge Innovation Project from the Chinese Academy of Sciences.

\section{References}

$\checkmark 1$ Kurita H: Disorders of the autism spectrum. Lancet 2006;368:179-181.

$\checkmark 2$ Newschaffer CJ, Croen LA, Daniels J, Giarelli E, Grether JK, Levy SE, Mandell DS, Miller LA, Pinto-Martin J, Reaven J, Reynolds AM, Rice CE, Schendel D, Windham GC: The epidemiology of autism spectrum disorders. Annu Rev Public Health 2007;28:235-258.

- 3 Fryns JP, Kleczkowska A: Autism and ring chromosome 18 mosaicism. Clin Genet 1992;42:55.

4 Herault J, Martineau J, Petit E, Perrot A, Sauvage $\mathrm{D}$, Barthelemy C, Mallet J, Muh JP, Lelord G: Genetic markers in autism: association study on short arm of chromosome 11. J Autism Dev Disord 1994;24:233-236.

5 Vostanis P, Harrington R, Prendergast M, Farndon P: Case reports of autism with interstitial deletion of chromosome 17 (p11.2 p11.2) and monosomy of chromosome 5 (5pter->5p15.3). Psychiatr Genet 1994;4: 109-111.

Activity-Dependent Gene Expression and Autism
-6 Schroer RJ, Phelan MC, Michaelis RC, Crawford EC, Skinner SA, Cuccaro M, Simensen RJ, Bishop J, Skinner C, Fender D, Stevenson RE: Autism and maternally derived aberrations of chromosome 15q. Am J Med Genet 1998;76:327-336.

7 Ghaziuddin M, Burmeister M: Deletion of chromosome 2q37 and autism: a distinct subtype? J Autism Dev Disord 1999:29:259263.

-8 Folstein SE, Mankoski RE: Chromosome 7q: where autism meets language disorder? Am J Hum Genet 2000;67:278-281.

-9 Ogilvie CM, Moore J, Daker M, Palferman S, Docherty Z: Chromosome 22q11 deletions are not found in autistic patients identified using strict diagnostic criteria. IMGSAC. International Molecular Genetics Study of Autism Consortium. Am J Med Genet 2000;96: 15-17.

10 Steele MM, Al-Adeimi M, Siu VM, Fan YS Brief report: a case of autism with interstitial deletion of chromosome 13. J Autism Dev Disord 2001;31:231-234.
11 Smalley SL, Kustanovich V, Minassian SL, Stone JL, Ogdie MN, McGough JJ, McCracken JT, MacPhie IL, Francks C, Fisher SE, Cantor RM, Monaco AP, Nelson SF: Genetic linkage of attention-deficit/hyperactivity disorder on chromosome 16p13, in a region implicated in autism. Am J Hum Genet 2002; 71:959-963.

-12 Sutcliffe IS, Nurmi EL, Lombroso PJ: Genetics of childhood disorders: XLVII. Autism, part 6: duplication and inherited susceptibility of chromosome 15q11-q13 genes in autism. J Am Acad Child Adolesc Psychiatry 2003;42:253-256

13 Cohen BI: Rationale for further investigation of chromosome 16p13.3, a region implicated for autism. Autism 2004;8:445-447.

14 Wiesel TN, Hubel DH: Effects of visual deprivation on morphology and physiology of cells in the cats lateral geniculate body. J Neurophysiol 1963;26:978-993. 
15 Wiesel TN, Hubel DH: Single-cell responses in striate cortex of kittens deprived of vision in one eye. J Neurophysiol 1963;26:10031017.

16 Hubel DH, Wiesel TN: Early exploration of the visual cortex. Neuron 1998;20:401-412.

17 Katz LC, Shatz CJ: Synaptic activity and the construction of cortical circuits. Science 1996;274:1133-1138.

18 Cohen S, Greenberg ME: Communication between the synapse and the nucleus in neuronal development, plasticity, and disease. Annu Rev Cell Dev Biol 2008;24:183-209.

19 Flavell SW, Greenberg ME: Signaling mechanisms linking neuronal activity to gene expression and plasticity of the nervous system. Annu Rev Neurosci 2008;31:563-590.

- 20 Aizawa H, Hu SC, Bobb K, Balakrishnan K, Ince G, Gurevich I, Cowan M, Ghosh A: Dendrite development regulated by crest, a calcium-regulated transcriptional activator. Science 2004;303:197-202.

-21 Ince-Dunn G, Hall BJ, Hu SC, Ripley B, Huganir RL, Olson JM, Tapscott SJ, Ghosh A: Regulation of thalamocortical patterning and synaptic maturation by NeuroD2. Neuron 2006;49:683-695.

-22 Kashani AH, Qiu Z, Jurata L, Lee SK, Pfaff S, Goebbels S, Nave KA, Ghosh A: Calcium activation of the lmo4 transcription complex and its role in the patterning of thalamocortical connections. J Neurosci 2006;26:83988408.

-23 Qiu Z, Ghosh A: A calcium-dependent switch in a CREST-BRG1 complex regulates activity-dependent gene expression. Neuron 2008;60:775-787.

24 Qiu Z, Ghosh A: A brief history of neuronal gene expression: Regulatory mechanisms and cellular consequences. Neuron 2008;60: 449-455.

$25 \mathrm{Wu}$ JI, Lessard J, Olave IA, Qiu Z, Ghosh A, Graef IA, Crabtree GR: Regulation of dendritic development by neuron-specific chromatin remodeling complexes. Neuron 2007; 56:94-108.

26 Lewis JD, Meehan RR, Henzel WJ, MaurerFogy I, Jeppesen P, Klein F, Bird A: Purification, sequence, and cellular localization of a novel chromosomal protein that binds to methylated DNA. Cell 1992;69:905-914.

27 Nan X, Campoy FJ, Bird A: MeCP2 is a transcriptional repressor with abundant binding sites in genomic chromatin. Cell 1997;88: 471-481.

28 Nan X, Ng HH, Johnson CA, Laherty CD, Turner BM, Eisenman RN, Bird A: Transcriptional repression by the methyl-CpGbinding protein $\mathrm{MeCP} 2$ involves a histone deacetylase complex. Nature 1998;393:386389.

-29 Amir RE, Van den Veyver IB, Wan M, Tran CQ, Francke U, Zoghbi HY: Rett syndrome is caused by mutations in X-linked MeCP2, encoding methyl-CpG-binding protein 2 . Nat Genet 1999;23:185-188.

30 Chahrour M, Zoghbi HY: The story of Rett syndrome: from clinic to neurobiology. Neuron 2007;56:422-437.
31 Tudor M, Akbarian S, Chen RZ, Jaenisch R: Transcriptional profiling of a mouse model for Rett syndrome reveals subtle transcriptional changes in the brain. Proc Natl Acad Sci USA 2002;99:15536-15541.

32 Chahrour M, Jung SY, Shaw C, Zhou X, Wong ST, Qin J, Zoghbi HY: MeCP2, a key contributor to neurological disease, activates and represses transcription. Science 2008; 320:1224-1229.

33 Chen WG, Chang Q, Lin Y, Meissner A, West AE, Griffith EC, Jaenisch R, Greenberg ME: Derepression of BDNF transcription involves calcium-dependent phosphorylation of MeCP2. Science 2003;302:885-889.

- 34 Martinowich K, Hattori D, Wu H, Fouse S, He F, Hu Y, Fan G, Sun YE: DNA methylation-related chromatin remodeling in activity-dependent BDNF gene regulation. Science 2003;302:890-893.

- 35 Klein ME, Lioy DT, Ma L, Impey S, Mandel G, Goodman RH: Homeostatic regulation of MeCP2 expression by a CREB-induced microRNA. Nat Neurosci 2007;10:1513-1514.

36 Chang Q, Khare G, Dani V, Nelson S, Jaenisch R: The disease progression of MeCP2 mutant mice is affected by the level of BDNF expression. Neuron 2006;49:341-348.

37 Guy J, Hendrich B, Holmes M, Martin JE, Bird A: A mouse MeCP2-null mutation causes neurological symptoms that mimic Rett syndrome. Nat Genet 2001;27:322-326.

38 Shahbazian M, Young J, Yuva-Paylor L, Spencer C, Antalffy B, Noebels J, Armstrong D, Paylor R, Zoghbi H: Mice with truncated MeCP2 recapitulate many Rett syndrome features and display hyperacetylation of histone H3. Neuron 2002;35:243-254

39 Gemelli T, Berton O, Nelson ED, Perrotti LI, Jaenisch R, Monteggia LM: Postnatal loss of methyl-CpG binding protein 2 in the forebrain is sufficient to mediate behavioral aspects of Rett syndrome in mice. Biol Psychiatry 2006;59:468-476.

40 Belichenko PV, Wright EE, Belichenko NP, Masliah E, Li HH, Mobley WC, Francke U: Widespread changes in dendritic and axonal morphology in MeCP2-mutant mouse models of Rett syndrome: evidence for disruption of neuronal networks. J Comp Neurol 2009; 514:240-258.

41 Dani VS, Chang Q, Maffei A, Turrigiano GG, Jaenisch R, Nelson SB: Reduced cortical activity due to a shift in the balance between excitation and inhibition in a mouse mode of Rett syndrome. Proc Natl Acad Sci USA 2005; 102:12560-12565.

42 Chao HT, Zoghbi HY, Rosenmund C: MeCP2 controls excitatory synaptic strength by regulating glutamatergic synapse number. Neuron 2007:56:58-65.

43 Nelson ED, Kavalali ET, Monteggia LM MeCP2-dependent transcriptional repression regulates excitatory neurotransmission. Curr Biol 2006;16:710-716

44 Moretti P, Levenson JM, Battaglia F, Atkinson R, Teague R, Antalffy B, Armstrong D, Arancio O, Sweatt JD, Zoghbi HY: Learning and memory and synaptic plasticity are impaired in a mouse model of Rett syndrome. J Neurosci 2006;26:319-327.
45 Moretti P, Bouwknecht JA, Teague R, Paylor R, Zoghbi HY: Abnormalities of social interactions and home-cage behavior in a mouse model of Rett syndrome. Hum Mol Genet 2005; 14:205-220

46 Matsuura T, Sutcliffe JS, Fang P, Galjaard RJ, Jiang YH, Benton CS, Rommens JM, Beaudet AL: De novo truncating mutations in E6-AP ubiquitin-protein ligase gene (UBE3A) in Angelman syndrome. Nat Genet 1997;15:7477.

47 Kishino T, Lalande M, Wagstaff J: UBE3A/ E6-AP mutations cause Angelman syndrome. Nat Genet 1997;15:70-73.

48 Kwasnicka-Crawford DA, Roberts W, Scherer SW: Characterization of an autism-associated segmental maternal heterodisomy of the chromosome 15q11-13 region. J Autism Dev Disord 2007;37:694-702.

49 Thatcher KN, Peddada S, Yasui DH, Lasalle JM: Homologous pairing of 15q11-13 imprinted domains in brain is developmentally regulated but deficient in Rett and autism samples. Hum Mol Genet 2005; 14:785-797.

50 Dykens EM, Sutcliffe JS, Levitt P: Autism and $15 \mathrm{q} 11-\mathrm{q} 13$ disorders: Behavioral, genetic, and pathophysiological issues. Ment Retard Dev Disabil Res Rev 2004;10:284-291.

51 Bundey S, Hardy C, Vickers S, Kilpatrick MW, Corbett JA: Duplication of the 15q1113 region in a patient with autism, epilepsy and ataxia. Dev Med Child Neurol 1994;36: 736-742.

52 Varshavsky A: Recent studies of the ubiquitin system and the $\mathrm{N}$-end rule pathway. Harvey Lect 2000;96:93-116.

53 Gusella JF, MacDonald ME: Huntington's disease and repeating trinucleotides. N Engl J Med 1994;330:1450-1451.

54 Gusella JF, Gilliam TC, Tanzi RE, MacDonald ME, Cheng SV, Wallace M, Haines J, Conneally PM, Wexler NS: Molecular genetics of Huntington's disease. Cold Spring Harb Symp Quant Biol 1986;51:359-364.

55 Shao J, Diamond MI: Polyglutamine diseases: emerging concepts in pathogenesis and therapy. Hum Mol Genet 2007;16:R115R123.

56 Cummings CJ, Orr HT, Zoghbi HY: Progress in pathogenesis studies of spinocerebellar ataxia type 1 . Philos Trans R Soc Lond B Biol Sci 1999;354:1079-1081.

57 Orr HT, Zoghbi HY: Toward understanding polyglutamine-induced neurological disease in spinocerebellar ataxia type 1. Cold Spring Harb Symp Quant Biol 1996;61:649-657.

58 Sato M, Stryker MP: Genomic imprinting of experience-dependent cortical plasticity by the ubiquitin ligase gene ube3a. Proc Natl Acad Sci USA.

59 Yashiro K, Riday TT, Condon KH, Roberts AC, Bernardo DR, Prakash R, Weinberg RJ, Ehlers MD, Philpot BD: Ube3a is required for experience-dependent maturation of the neocortex. Nat Neurosci 2009;12:777-783.

60 Scheffner M, Huibregtse JM, Vierstra RD, Howley PM: The HPV-16 E6 and E6-AP complex functions as a ubiquitin-protein ligase in the ubiquitination of p53. Cell 1993; 75:495-505. 
-61 Huibregtse JM, Scheffner M, Howley PM: Localization of the E6-AP regions that direct human papillomavirus E6 binding, association with p53, and ubiquitination of associated proteins. Mol Cell Biol 1993;13:49184927.

-62 Greer PL, Hanayama R, Bloodgood BL, Mardinly AR, Lipton DM, Flavell SW, Kim TK, Griffith EC, Waldon Z, Maehr R, Ploegh HL, Chowdhury S, Worley PF, Steen J, Greenberg ME: The Angelman syndrome protein Ube3A regulates synapse development by ubiquitinating arc. Cell 2010;140: 704-716.

-63 Shepherd JD, Rumbaugh G, Wu J, Chowdhury S, Plath N, Kuhl D, Huganir RL, Worley PF: Arc/Arg3.1 mediates homeostatic synaptic scaling of AMPA receptors. Neuron 2006; 52:475-484.

64 Rial Verde EM, Lee-Osbourne J, Worley PF, Malinow R, Cline HT: Increased expression of the immediate-early gene Arc/Arg3.1 reduces AMPA receptor-mediated synaptic transmission. Neuron 2006;52:461-474.

65 Chowdhury S, Shepherd JD, Okuno H, Lyford G, Petralia RS, Plath N, Kuhl D, Huganir RL, Worley PF: Arc/Arg3.1 interacts with the endocytic machinery to regulate AMPA receptor trafficking. Neuron 2006;52:445459.

- 66 Durand CM, Betancur C, Boeckers TM, Bockmann J, Chaste P, Fauchereau F, Nygren G, Rastam M, Gillberg IC, Anckarsater H, Sponheim E, Goubran-Botros H, Delorme R, Chabane N, Mouren-Simeoni MC, de Mas P, Bieth E, Roge B, Heron D, Burglen L, Gillberg C, Leboyer M, Bourgeron T: Mutations in the gene encoding the synaptic scaffolding protein SHANK3 are associated with autism spectrum disorders. Nat Genet 2007;39:2527.

-67 Sykes NH, Toma C, Wilson N, Volpi EV, Sousa I, Pagnamenta AT, Tancredi R, Battaglia A, Maestrini E, Bailey AJ, Monaco AP, International Molecular Genetic Study of Autism Consortium (IMGSAC): Copy number variation and association analysis of SHANK3 as a candidate gene for autism in the IMGSAC collection. Eur J Hum Genet 2009;17:13471353.

68 Geschwind DH: Autism: the ups and downs of neuroligin. Biol Psychiatry 2009;66:904905.

69 Jamain S, Quach H, Betancur C, Rastam M, Colineaux C, Gillberg IC, Soderstrom H, Giros B, Leboyer M, Gillberg C, Bourgeron T: Mutations of the X-linked genes encoding neuroligins NLGN3 and NLGN4 are associated with autism. Nat Genet 2003;34:27-29.

-70 Naisbitt S, Kim E, Tu JC, Xiao B, Sala C, Valtschanoff J, Weinberg RJ, Worley PF, Sheng M: Shank, a novel family of postsynaptic density proteins that binds to the NMDA receptor/PSD-95/GKAP complex and cortactin. Neuron 1999;23:569-582.
1 Sala C, Piech V, Wilson NR, Passafaro M, Liu G, Sheng M: Regulation of dendritic spine morphology and synaptic function by Shank and Homer. Neuron 2001;31:115-130.

72 Roussignol G, Ango F, Romorini S, Tu JC, Sala C, Worley PF, Bockaert J, Fagni L: Shank expression is sufficient to induce functional dendritic spine synapses in aspiny neurons. J Neurosci 2005; 25:3560-3570.

73 Ushkaryov YA, Petrenko AG, Geppert M, Sudhof TC: Neurexins: Synaptic cell surface proteins related to the alpha-latrotoxin receptor and laminin. Science 1992;257:50-56.

74 Ichtchenko K, Hata Y, Nguyen T, Ullrich B, Missler M, Moomaw C, Sudhof TC: Neuroligin 1: a splice site-specific ligand for betaneurexins. Cell 1995;81:435-443.

75 Graf ER, Zhang X, Jin SX, Linhoff MW Craig AM: Neurexins induce differentiation of GABA and glutamate postsynaptic specializations via neuroligins. Cell 2004;119: 1013-1026.

76 Chih B, Engelman H, Scheiffele P: Control of excitatory and inhibitory synapse formation by neuroligins. Science 2005;307:1324-1328.

77 Varoqueaux F, Aramuni G, Rawson RL, Mohrmann R, Missler M, Gottmann K, Zhang W, Sudhof TC, Brose N: Neuroligins determine synapse maturation and function. Neuron 2006;51:741-754.

78 Blundell J, Blaiss CA, Etherton MR, Espinosa F, Tabuchi K, Walz C, Bolliger MF, Sudhof TC, Powell CM: Neuroligin-1 deletion results in impaired spatial memory and increased repetitive behavior. J Neurosci 2010; 30:2115-2129.

79 Tabuchi K, Blundell J, Etherton MR, Hammer RE, Liu X, Powell CM, Sudhof TC: A neuroligin-3 mutation implicated in autism increases inhibitory synaptic transmission in mice. Science 2007;318:71-76.

80 Ramocki MB, Peters SU, Tavyev YJ, Zhang F, Carvalho CM, Schaaf CP, Richman R, Fang P, Glaze DG, Lupski JR, Zoghbi HY: Autism and other neuropsychiatric symptoms are prevalent in individuals with MeCP2 duplication syndrome. Ann Neurol 2009;66:771782 .

81 Zhang F, Gu W, Hurles ME, Lupski JR: Copy number variation in human health, disease, and evolution. Annu Rev Genomics Hum Genet 2009;10:451-481.

-82 Collins AL, Levenson JM, Vilaythong AP, Richman R, Armstrong DL, Noebels JL, David Sweatt J, Zoghbi HY: Mild overexpression of MeCP2 causes a progressive neurological disorder in mice. Hum Mol Genet 2004;13:2679-2689.

83 Salmon B, Hallmayer J, Rogers T, Kalaydjieva L, Petersen PB, Nicholas P, Pingree C, McMahon W, Spiker D, Lotspeich L, Kraemer $\mathrm{H}$, McCague P, Dimiceli S, Nouri N, Pitts T, Yang J, Hinds D, Myers RM, Risch N: Absence of linkage and linkage disequilibrium to chromosome 15q11-q13 markers in 139 multiplex families with autism. Am J Med Genet 1999;88:551-556.
84 Nakatani J, Tamada K, Hatanaka F, Ise S, Ohta $\mathrm{H}$, Inoue $\mathrm{K}$, Tomonaga $\mathrm{S}$, Watanabe $\mathrm{Y}$, Chung YJ, Banerjee R, Iwamoto K, Kato T, Okazawa M, Yamauchi K, Tanda K, Takao K, Miyakawa T, Bradley A, Takumi T: Abnormal behavior in a chromosome-engineered mouse model for human 15q11-13 duplication seen in autism. Cell 2009;137:12351246.

85 Kishore S, Khanna A, Zhang Z, Hui J, Balwierz PJ, Stefan M, Beach C, Nicholls RD, Zavolan M, Stamm S: The snoRNA MBII-52 (SNORD 115) is processed into smaller RNAs and regulates alternative splicing. Hum Mol Genet 2010;19:1153-1164.

86 Kishore S, Stamm S: The snoRNA HBII-52 regulates alternative splicing of the serotonin receptor 2C. Science 2006;311:230232.

87 Luikenhuis S, Giacometti E, Beard CF, Jaenisch R: Expression of MeCP2 in postmitotic neurons rescues Rett syndrome in mice. Proc Natl Acad Sci USA 2004;101:60336038.

88 Guy J, Gan J, Selfridge J, Cobb S, Bird A: Reversal of neurological defects in a mouse model of Rett syndrome. Science 2007;315: 1143-1147.

89 Giacometti E, Luikenhuis S, Beard C, Jaenisch R: Partial rescue of MeCP2 deficiency by postnatal activation of MeCP2. Proc Natl Acad Sci USA 2007;104:1931-1936.

90 Gray SJ, Blake BL, Criswell HE, Nicolson SC, Samulski RJ, McCown TJ: Directed evolution of a novel adeno-associated virus (AAV) vector that crosses the seizure-compromised blood-brain barrier (BBB). Mol Ther 2010; 18:570-578.

-91 van Woerden GM, Harris KD, Hoijati MR, Gustin RM, Qiu S, de Avila Freire R, Jiang YH, Elgersma Y, Weeber EJ: Rescue of neurological deficits in a mouse model for Angelman syndrome by reduction of alphaCaMKII inhibitory phosphorylation. Nat Neurosci 2007;10:280-282.

92 Tropea D, Giacometti E, Wilson NR, Beard C, McCurry C, Fu DD, Flannery R, Jaenisch R, Sur M: Partial reversal of Rett syndromelike symptoms in MeCP2 mutant mice. Proc Natl Acad Sci USA 2009;106:2029-2034.

-93 Lanford RE, Hildebrandt-Eriksen ES, Petri A, Persson R, Lindow M, Munk ME, Kauppinen S, Orum H: Therapeutic silencing of microRNA-122 in primates with chronic hepatitis C virus infection. Science 2010;327: 198-201.

94 Morrow EM, Yoo SY, Flavell SW, Kim TK, Lin Y, Hill RS, Mukaddes NM, Balkhy S, Gascon G, Hashmi A, Al-Saad S, Ware J, Joseph RM, Greenblatt R, Gleason D, Ertelt JA, Apse KA, Bodell A, Partlow JN, Barry B, Yao H, Markianos K, Ferland RJ, Greenberg ME, Walsh CA: Identifying autism loci and genes by tracing recent shared ancestry. Science 2008;321:218-223. 